\title{
遺伝子組み換えサケ、承認へ
}

\section{Transgenic fish go large}

EMma MARRIS 2010 年 9 月 16 日号 Vol. 467 (259)

www.nature.com/news/2010/100914/full/467259a.html

まもなく、食用の遺伝子組み換え動物としてサケが初めて認可される見込みである。 今後、他の遺伝子組み換え動物食品が次々と市場に出回るようになるかもしれない。

米国では、初の遺伝子組み換え動物がま もなく食卓に上ろうとしている。米国食 品医薬品局（FDA）が、野生種の 2 倍の 速さで成長する遺伝子組み換え $(\mathrm{GM})$ タイセイヨウサケ(アトランティックサー モン）を承認するとみられているのだ。

この遺伝子組み換えサケは、出荷でき るサイズになるまで、通常なら 3 年か かるところが 1 年半ですむ。このサケ は、マスノスケ (キングサーモン) の成 長ホルモンの遺伝子配列とウナギに似た ゲンゲの調節配列を含む DNA 配列を 1 コピーもつ。このため、通常のタイセイ ヨウサケは冬に成長しないのだが、遺伝 子組み換えサケは年間を通じて成長ホル モンを作り続けることができ、一年中成 長する。開発したアクアバウンティ・テ クノロジーズ社（米国マサチューセッッ 州ウォルサム）は、新しい規制の枠組み の中で、10 年以上をかけてこの魚の承 認をめざしてきた。

2009 年、FDA は、動物の遺伝子組み 換え形質を獣医薬品として分類すること を決定した。この決定に対しては、企業
が遺伝子組み換え製品の詳細を機密情報 として非公表とすることを許すものだと いう批判があった ${ }^{1}$ 。批判を鎮めるため、 FDA は遺伝子組み換えサケに関する決 定事項についてすべての情報をインター ネット上に公表し、諮問機関である「獣 医学諮問委員会 $(\mathrm{VMAC}) 」 に よ る$ 審議 の大部分を公開した。そして、9月 19 日と 20 日にVMAC は、この魚の科学、 安全性、環境に対する影響、および表示 法について詳しく聞くための公開諮問会 議を開く。VMAC の報告を受けて承認 に関する決定を行う FDA の獣医学セン ターは、既に前向きの報告書を公表して いる。(編集部註:この公開諮問会議では、 「食べても安全である」との見解が示さ れたが、FDA はさらなる試験が必要と して承認を先送りした。11月10日現在、 未承認である。)

環境団体の中には、遺伝子組み換えサ ケが尘け員から逃げて野生のタイセイヨ ウサケとの交配が起こることを懸念する ものもある。モントレー・ベイ水族館 (米 国カリフォルニア州）で水産養殖研究の

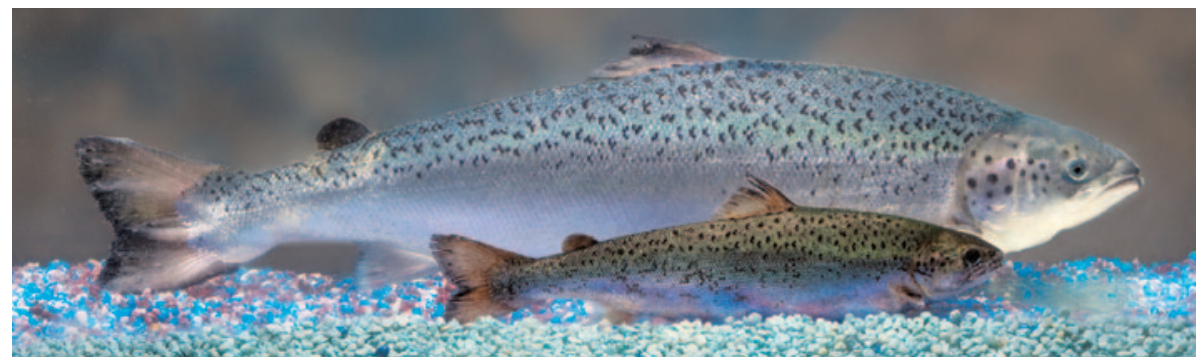

遺伝子組み換えアトランティックサーモン (後方)。手前の野生種に比べて、その巨大さは一 目瞭然である。
責任者を務める Peter Bridson は、「遺 伝子組み換えサケが逃げる危険性は常に 付きまといます。ですから私は、今回の 申請の承認には反対です」と話す。

アクアバウンティ社の最高経営責任者 である Ronald Stotish は、そうした懸 念は見当違いだと語る。同社の遺伝子組 み換えサケの 99 パーセント以上は、三 倍体であるために生殖能力がない。また、 飼育されているのは内陸部で、巨大な飼 育水槽には卵や幼魚、成魚を閉じ込める ためのフィルターと隔壁が備え付けられ ている。「野生の魚たちとの交配につな がりかねない流出などのトラブルが発生 するリスクは、ないに等しいのです」と Stotish は説く。

メモリアル大学（カナダ・ニューファ ンドランド州セントジョンズ）の生物 学者である Mark Abrahamsによれば、 この遺伝子組み換えサケの旺盛な代謝は 自然界の生存には適していないという。 「わざわざ捕食されるリスクを負うよう になっている」つまり肉食動物に食べ られやすいということなのだ。

サケの次に食卓に上りそうな遺伝子組 み換え動物は、グエルフ大学（カナダ・ オンタリオ州）で開発され、現在 FDA の承認を待っている「エンバイロピッ グ」だ。この遺伝子組み換えブタは慨か らリンを効率的に取り込むことができる ため、糞便に含まれるリンが少ない。リ ンの多い糞便は、水路に藻の大発生をも たらす場合があるのだ。

EU では審査待ちの食用遺伝子組み換 え動物はなく、欧州食品安全機関（イ夕 リア・パルマ）が規制の指針を起草し始 めたところだ。今のところ、アクアバウ ンティ社は米国内だけで遺伝子組み換え サケを売ろうとしている。「ほかの国も 興味はあるのですが、どこも米国の承認 の様子見をしているのです」と Stotish は語る。

(翻訳：小林盛方)

1. http://www.nature.com/news/2008/080919/full/ news.2008.1120.html 